Relations industrielles

Industrial Relations

\title{
Crise de confiance
}

\section{A Crisis of Distrust}

Volume 1, numéro 3, novembre 1945

URI : https://id.erudit.org/iderudit/1023906ar

DOI : https://doi.org/10.7202/1023906ar

Aller au sommaire du numéro

Éditeur(s)

Département des relations industrielles de l’Université Laval

ISSN

0034-379X (imprimé)

1703-8138 (numérique)

Découvrir la revue

Citer cet article

(1945). Crise de confiance / A Crisis of Distrust. Relations industrielles /

Industrial Relations, 1(3), 1-7. https://doi.org/10.7202/1023906ar

Tous droits réservés (C Département des relations industrielles de l’Université Laval, 1945
Ce document est protégé par la loi sur le droit d'auteur. L’utilisation des services d'Érudit (y compris la reproduction) est assujettie à sa politique d'utilisation que vous pouvez consulter en ligne.

https://apropos.erudit.org/fr/usagers/politique-dutilisation/ 


\section{Bulletin des Relations Industrielles}

PUBLIÉ PAR LE DÉPARTEMENT DES RELATIONS INDUSTRIELLES

de LA FACULTE des SCIENCES SOCIALES DE LAVAL, QuÉbeC

Dans ce numbro:

Clauces de retenue des cotieations syndicales...................

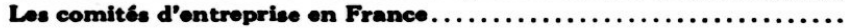

In this issue:

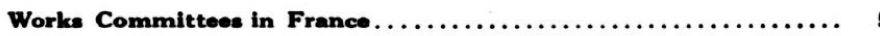

Eecential Elements of Trade Union Agreoments..................

\section{CRISE DE CONFIANCE}

Le Canada traverse une crise de confiance très grave. Dans diverses régions, des grèves nombreuses opposent les employeurs et les travailleurs. Nous ne portons pas de jugement sur ces conflits d'intérêts, car nous n'avons pas à notre disposition tous les éléments nécessaires, sans compter que les problèmes industriels sont très complexes. Quelles que soient les véritables causes de ces différends, il reste que la violation des lois, la faiblesse de l'autorité et l'absence de confiance chez les uns et les autres sont les caractéristiques dominantes du désordre actuel.

Lorsqu'on examine l'évolution des relations industrielles depuis une dizaine d'années, on est frappé par le chemin parcouru en matière de légielation du travail. Aussi bien au Canada que dans les autres pays, les gouvernements provinciaux et le gouvernement fédéral (temporairement en vertu de la loi des mesures de guerre) ont adopté des lois qui semblent répondre aux besoins présents. Faut-il attribuer les troubles d'aujourd'hui à l'insuffisance de la législation ?

Personne ne prétend que la législation ouvrière soit parfaite et définitive. Mais, avant de mettre en cause la législation elle-même, il convient de se demander si les employeurs, tout comme les associations ouvrières, respectent l'esprit et la lettre de cette législation. A ce sujet, il serait significatif de relever les actes des employeurs et des syndicats qui furent manifestement une violation des lois. Ce relevé statistique révélerait qu'au respect de la législation on substitue trop souvent le poids des intérêts financiers ou celui des préoccupations démagogiques. On constaterait encore la faiblesse de l'autorité. Les lois ouvrières prévoient des sanctions contre ceux qui en violent les dispositions. Applique-ton souvent les sanctions prévues?

Ces carences amènent un mépris complet pour les lois et l'autorité responsable de leur application. Elles créent des précédents dont l'autorité devient l'esclave. Il en résulte des situations compliquées qui sont une menace pour l'ordre public et la protection des intérêts

(Suite d la page ?)

\section{A CRISIS OF DISTRUST}

Actually Canada is in the midst of a very serious crisis of distrust. In various regions of our country numerous strikes are bringing employers and workers into mutual opposition. We do not intend hereby to judge such conflicts of interests, as we do not have at our disposal all the elements required; besides, such industrial problems are complicated. Whatever may be the real causes of these disputes, the fact remains that some of the most alarming aspects of the present disturbance are : violation of the laws, the weakness of authority, and distrust on the part of employers and employees.

A survey of the evolution of industrial relations during the last ten years reveals that labour legislation has greatly improved. In Canada, as well as elsewhere, the provincial governments and the federal government (temporarily in virtue of the War Measures Act) have passed laws which seem to meet present needs. Must one conclude that the actual labour troubles are due to a deficiency of the legislation ?

Nobody would claim that our labour legislation is absolutely perfect and definite, but, before blaming the legislation proper, it would be most timely to ask if the employers, as well as the workers, always respect the spirit and the letter of this legislation. In this respect it would be significant to draw up an account of the acts of employers and syndicates which have constituted a manifest violation of the laws. Such statistics would reveal that the weight of financial interests or demagogic preoccupations are too often substituted for honest respect of the law. The weakness of authority would also be noticed. The labour laws provide penalties for those who transgress their provisions. Are the necessary sanctions often applied?

Such defaulting breeds complete contempt of the laws as well as of the authority which is responsible for their application ; it creates precedents to which authority becomes a slave. Complicated situations are brought about and thus constitute a threat to public

(Continued on page $\gamma$ ) 


\section{CLAUSES DE RETENUE DES COTISATIONS SYNDICALES}

Dans le dernier numéro du Bulletin des Relations Industrielles, nous avons fait un bref exposé de la sécurité syndicale et en avons défini les principales clauses qui peuvent être discutées entre employeurs et employés, pour être ensuite incluses dans une convention collective. Nous voulons faire ici une étude plus détaillée d'une clause particulière : celle de la retenue des cotisations syndicales. Notre seul but est d'éclairer les négociateurs dans le travail difficile qu'ils ont à accomplir et de leur éviter, si possible, d'inutiles discussions. Nous désirons également leur rendre plus facile la rédaction d'une clause sur laquelle ils se sont entendus et, à cette fin, nous proposons différents modèles susceptibles de s'adapter à différents cas particuliers.

\section{La retenue des cotisations syndicales :}

La retenue syndicale (1) peut comprendre les seules cotisations mensuelles imposées à chaque membre par le syndicat, mais aussi, les autres dettes que le membre peut contracter ou avoir contractées envers celui-ci, telles, par exemple, la taxe d'initiation, les cotisations extraordinaires, ou encore certaines amendes imposées pour infraction à la discipline.

Nous a vons déjà noté qu'il est illégal pour l'employeur de faire, à même le salaire de ses employés, des déductions autres que celles requises par la loi, comme les cotisations imposées par la Commission d'assurancechômage, la Commission des accidents du travail, les comités paritaires, etc. Dans tous les cas, pour que la retenue syndicale soit légale, il faut une autorisation écrite de la part des employés concernés. Mais cette autorisation peut être révocable ou non, pendant la durée de la convention. On comprend facilement que nous ne tenions pas compte d'une certaine forme de retenue syndicale déjà proposée par une union ouvrière, laquelle consistait, en somme, à lier perpétuellement un employé à son syndicat, car on lui faisait signer une formule par laquelle il autorisait l'employeur à déduire toutes ses dettes envers le syndicat " aussi longtemps qu'il demeurait à l'emploi de l'entreprise ").

Enfin, une autre particularité. L'employeur peut opérer cette perception gratuitement ou bien il peut charger au syndicat un certain montant pour se dédommager des frais encourus par une telle perception. Certaines gens voient là une question de principe à laquelle les employeurs doivent tenir puisqu'ils se trouvent, en somme, à accomplir un travail qui revient en propre au syndicat. D'aụtres considèrent que c'est là une question de détail et que les employeurs qui acceptent le syndicalisme sans arrière-pensée et qui veulent vraiment collaborer ne doivent pas en tenir compte, étant donné qu'ils agissent souvent de la sorte pour le maintien d'œuvres, recommandables il est vrai, mais qui intéressent bien indirectement les ouvriers. En fait, les syndicats se font généralement un point d'honneur de ne pas discuter cette question et ils acceptent facilement de payer les frais de perception.

(1) L'expression anglaise est check off et la traduction qui paraftrait la plus parfaite serait " le décompte syndical ".
Voici comment on pourrait rédiger une clause de retenue syndicale, en tenant compte des différentes modalités dont il a été question.

article...

a) Au reçu de l'autorisation écrite donnée dans la formule prescrite par la clause b) du présent article, la compagnie s'engage, pour la durée légale de ladite autorisation, à retenir sur la paye de l'employé, au premier (ou dernier, etc.) jour de paye de chaque mois, pendant la durée de cette convention, le montant de cotisations syndicales (et ajouter, si l'on veut : "et de toute dette envers le syndicat "), dont la déduction est ainsi autorisée, et à transmettre le total de ces sommes à (dirigeant désigné par le syndicat)..., soit le premier jour du mois suivant, soit avant.

b) Les deux parties acceptent que il la formule prescrite " mentionnée dans la clause $a$ ) de cet article soit rédigée comme suit :

" Je . ... employé de . . . (nom de la compagnie) ..., à ... (nom de l'endroit) . . . et membre du syndicat .... (nom du syndicat) .... donne par la présente a... (nom de la compagnie)..., l'autorisation et l'instruction de retenir chaque mois, au premier (ou dernier, etc.) jour de paye du mois, sur tous les gains accumulés à mon actif, le montant de ma cotisation syndicale mensuelle (et ajouter, si l'on veut : " et de toutes mes dettes ") due au Syndicat ... (nom) ...."

" J'autorise en plus ... (nom de la compagnie) ... à verser les sommes ainsi déduites à... (dirigeant désigné par le syndicat) ... dont le regu constituera pour la compagnie une quittance valable et suffisante pour les montants ainsi déduits de mes gains. "

Telle quelle, cette formule ne mentionne point la durée de la validité de cette autorisation. Aussi, est-il nécessaire d'ajouter une limite de temps. On a le choix entre la retenue révocable et la retenue irrévocable. Mais, de toute façon, l'une ou l'autre doit être déterminée.

Si l'on désire que l'autorisation soit irrévocable, on ajoutera le paragraphe suivant :

I Cette autorisation sera valable pendant toute la durée légale de cette convention. "

Si l'on désire que l'autorisation soit révocable, on ajoutera ce qui suit :

( Je me réserve le droit d'annuler cette autorisation, quand bon me semblera, moyennant avis de... (quinze jours, un mois, deux mois) ... adressé à . . . (nom de l'entreprise)."

Et les employeurs exigent généralement, dans ce cas, que l'on ajoute, afin de ne point compliquer leur comptabilité :

" et j'accepte qu'en cas d'annulation, l'autorisation ne puisse pas être renouvelée avant l'expiration d'une autre période de... (quinze jours, un mois) ").

Il est bien entendu que cette autorisation doit être signée par l'employé-lui-même devant témoin et faire mention de la date et de l'endroit.

(Suite d la page 4) 


\section{LES COMITÉS D'ENTREPRISE EN FRANCE}

Parmi les aspirations légitimes (1) de la classe ouvrière, la participation à l'administration des entreprises présente un intérêt particulier. Aujourd'hui, les ouvriers réclament non seulement des salaires et des conditions de travail convenables, mais ils désirent jouer un rôle à l'intérieur de l'entreprise, bref, participer à sa gestion. C'est un problème d'actualité qu'il importe d'envisager objectivement.

La participation peut revêtir trois formes : a) de conseil ; b) de contrôle ; c) de cogestion. Les deux premières modalités ne portent pas atteinte aux prérogatives essentielles du Capital ou du chef d'entreprise, alors que la troisième place sur le même pied travailleurs et actionnaires.

$A$. - Au Canada, de même qu'en Grande-Bretagne et aux Etats-Unis, la participation sous forme de conseil a donné des résultats tangibles; particulièrement dans les industries de guerre. En effet, les comités mixtès de production ont associé étroitement les travailleurs à la solution des problèmes techniques de la production. Sans empiéter sur le.domaine propre des syndicats, ces comités ont comblé une lacune qui existait auparavant dans les relations industrielles.

B. - En France, le Gouvernement provisoire a adopté, en février 1945, une ordonnance instituant des comités d'entreprise. Accédant à une ancienne revendication syndicale, le ministre du Travail a institué $l a$ participation sous forme de contrôle, évitant ainsi la participation sous forme de cogestion réclamée en certains milieux. Les comités d'entreprise français ont un champ d'action plus vaste et un rôle plus étendu que nos comités mixtes de production. Ils doivent assurer, au sein des entreprises, une collaboration efficace entre les différents éléments concourant à la production : chefs d'entreprises, techniciens et salariés. Les syndicats désignent les candidats qu'ils désirent voir siéger sur les comités ; ces candidats ont ensuite toute liberté d'agir indépendamment des directives des syndicats. Les comités d'entreprise exercent leurs fonctions sur le plan social et le plan économique.

$1^{\circ}$ Sur le plan social, les comités ont pour mission d'améliorer les conditions de travail, excepté les salaires qui relèvent de l'action syndicale propre. De plus, ils assurent l'administration de toutes les ouvres sociales établies dans les entreprises au bénéfice des salariés ou de leurs familles.

$2^{\circ}$ Sur le plan économique, les comités d'entreprise ne jouent qu'un rôle consultatif et ils n'ont qu'un droit de regard. A titre consultatif, les comités ont les attributions suivantes : a) ils étudient toutes les suggestions émises par le personnel en vue d'accroître la production et d'améliorer le rendement des entreprises et proposent l'application de celles qu'ils jugent opportunes : b) ils

(1) Nous estimons, cependant, plus approprié aux conditions présentes de la vie sociale, de tempérer quelque peu, dans la mesure du possible, le contrat de travail par des éléments empruntés au contrat de société. C'est ce que l'on a déjà commencé à faire, sous des formes variées, non sans profit sensible pour les travailleurs et pour les possesseurs du capital. Ainsi, les ouvriers et les employés ont été appelés à participer en quelque manière à la propriété de l'entreprise, a sa gestion ou aux profits qu'elle apporte ». Quadragesimo Anno. proposent en faveur des travailleurs ayant apporté par leur initiative ou leurs propositions une collaboration particulièrement utile à l'entreprise, toute récompense qui leur semble méritée; c) ils sont obligatoirement injormés des questions intéressant l'organisation, la gestion et la marche générale de l'entreprise. Les chefs d'entreprises doivent faire, au moins une fois par an, un exposé de la situation et des activités de leur organisation et soumettre leurs projets pour l'exercice suivant. De plus, lorsque l'entreprise est constituée sous la forme d'une société par action ou qu'elle réunit d'une façon continue, quelle que soit sa forme, plus de cinq cents salariés, le comité est, en outre, informé des bénéfices réalisés et peut émettre des suggestions sur leur emploi. Enfin, dans les entreprises qui revêtent la forme d'une société anonyme, la direction est tenue de communiquer au comité, avant de les présenter à l'assemblée générale des actionnaires, le compte de profits et pertes, le bilan annuel et le rapport des commissaires aux comptes ainsi que les autres documents qui seraient soumis à telle assemblée générale. Voilà, en résumé, les principales dispositions de l'ordonnance de février 1945.

C. - La participation sous forme de cogestion est évidemment plus complète. En pareil cas, les représentants des travailleurs sont sur un pied d'égalité avec les représentants des actionnaires. Les comités de cogestion sont dotés d'un pouvoir de décision et de commandement, alors que les comités d'entreprise n'ont qu'un rôle consultatif et un droit de regard.

Ce bref exposé suffit à démontrer les différences qui existent entre nos comités mixtes de production et les comités d'entreprise. Alors que ceux-ci ont un caractère général, permanent et obligatoire, ceux-là sont volontaires. Non seulement les comités d'entreprise ont des pouvoirs beaucoup plus étendus, mais les employeurs ne peuvent s'opposer à leur formation. Cette formule est un compromis entre la cogestion intégrale de l'entreprise et la simple participation à la gestion sous forme de conseil. Sur le plan social, les travailleurs ont un pouvoir d'administration alors que sur le plan économique, leur rôle n'est que consultatif.

Néanmoins, l'ordonnance française représente une réforme audacieuse que plusieurs considèrent comme un stage préalable imposé aux travailleurs avant de les admettre à siéger de plein droit dans les conseils d'administration. Toutes les organisations syndicales ont donné le mot d'ordre suivant : "Aux travailleurs de faire un succès des comités d'entreprise et ils pourront alors aspirer à la cogestion économique ". Un analyste objectif écrivait récemment : " L'ordonnance du 22 février 1945, en résumé, a sagement tenu compte des expériences étrangères. Elle a créé une institution compatible avec le régime capitaliste des entreprises actuelles et donc, a réformé celles-ci sans les bouleverser. Elle contient des dispositions qui assurent le maintien de l'autorité des chefs et d'autres garantissant que les rapports seront pacifiques entre les comités et les organisations syndicales "). Telle semble être l'opinion courante en France. 


\section{RÉADAPTATION AU TRAVAIL}

L'expérience des handicapés qui ont travaillé dans les usines de guerre laisse entrevoir des possibilités encourageantes pour les mutilés de la guerre ou pour les victimes d'accidents de travail. En effet, il est maintenant prouvé qu'une incapacité partielle permanente n'est pas un handicap insurmontable sur le marché du travail. C'est la conclusion qui se dégage d'une enquête conduite par le "Bureau of Labor Statistics " (Etats-Unis), en collaboration avec d'autres commissions gouvernementales (1). On a défini le travailleur handicapé comme suit : " un ouvrier marqué de déficiences physiques qui limitent sa capacité de travail s'il ne remplit pas une tâche appropriée ". Or, l'enquête a révélé qu'au point de vue du rendement, de l'absentéisme, de la fréquence accidentelle et du mouvement de la main-d' cuvre, le rendement des tra vailleurs handicapés se compare avantageusement, lorsqu'il n'est pas légèrement supérieur.

Devant ces faits, on ne peut qu'apprécier favorablement l'initiative du ministère du Travail de la province de Québec d'organiser, par l'intermédiaire de la Commission des accidents du travail, une clinique médicale et un service de réhabilitation. Aujourd'hui, la Commission ne s'occupe plus seulement de faire traiter les ouvriers blessés et de leur payer des prestations; grâce à ses nouveaux services, les travailleurs frappés d'incapacité partielle permanente peuvent retrouver une certaine dextérité qui leur permettra de se replacer avantageusement dans les entreprises. De plus, le service de réhabilitation entre en contact avec les employeurs en vue de trouver des emplois appropriés aux travailleurs dont la capacité de travail a été diminuée. C'est là une œuvre sociale par excellence.

Prévention, compensation, réadaptation : voilà les cadres d'un système complet. La province de Québec possède maintenant un tel système. Il reste aux employeurs et aux associations ouvrières de seconder les efforts de la Commission des accidents du travail.

(1) Monthly Labor Review, octobre 1944.

\section{CLAUSES DE RETENUE ...}

\section{(Suite de la page 2)}

Enfin, pour ce qui est des frais de perception, si l'employeur ne veut point les absorber, on peut ajouter aux clauses $a$ ) et $b$ ) la clause $c$ ) suivante :

c) Afin de se dédommager des frais encourus par la retenue syndicale, l'employeur se réserve le droit de charger au compte du syndicat... (généralement $1 / 2$ de $1 \%$ ) ... des sommes qu'il aura ainsi perçues en sa faveur.

Nous avons l'intention de faire, un peu plus tard, l'étude des autres principales clauses de sécurité syndicale : le maintien de l'affiliation syndicale, l'atelier syndical, la préférence syndicale, etc ...

\section{Gérard Dion.}

\section{SYNDICALISME ET ACTION POLITIQUE}

Les syndicats ouvriers ayant pour mission principale de défendre les droits des travailleurs, on conçoit qu'ils veuillent exercer leur influence dans tous les domaines où ils les croient en jeu. Aussi, ils ne limitent pas leur action à la seule amélioration des salaires et conditions de travail par le truchement des conventions collectives ; ils représentent également l'ensemble de la classe ouvrière auprès des autorités gouvernementales. C'est pourquoi ils ne manquent jamais une occasion de faire connaître l'opinion de leurs membres sur les questions politiques, économiques et sociales de l'heure. D'où aussi la difficulté pour eux de délimiter leur champ d'action, de déterminer où finit l'action syndicale et où commence l'action politique. Rappelons d'abord que les associations ouvrières semblent opposées à l'organisation d'un parti politique syndical. Au Canada aussi bien qu'aux Etats-Unis, toutes les tentatives faites dans ce sens ont échoué lamentablement. Cependant, les unions ouvrières ont élaboré, il y a quelques années, une formule originale: celle des comités d'action politique ${ }^{(1)}$.

Le comité d'action politique se consacre avant tout à l'éducation de ses membres. A l'occasion des campagnes électorales, le comité a pour mission de scruter les programmes des partis politiques en vue de bien s'assurer que ceux-ci n'entrent pas en conflit avec les principes des syndicats. Le comité profite encore des périodes électorales pour exposer sa doctrine et faire apprécier le rôle du syndicalisme dans la vie nationale. Un candidat qui serait manifestement opposé au syndicalisme et à la législation ouvrière subirait inévitablement le boycottage du comité d'action politique de sa circonscription.

En principe, il s'agit beaucoup plus d'intéresser les travailleurs à l'action politique que de les inciter à militer officiellement pour un parti politique spécifique. Les membres des syndicats sont invités à se rallier aux candidats, à quelque parti qu'ils appartiennent, qui sont disposés à promouvoir l'application des principes économiques et sociaux du syndicalisme. Mais en pratique, il semble difficile à un comité d'action politique d'éviter le danger d'affiliation directe à un parti politique, ce qui ne va pas sans créer de graves problèmes.

Au Canada, la Confédération des travailleurs catholiques s'oppose formellement à toute modalité d'action politique de la part de ses syndicats affiliés; par contre, le Congrès canadien du Travail et le Congrès des Métiers et du Travail ont fait leur cette formule d'action politique inspirée du C. I. 0 . 


\section{WORKS COMMITTEES IN FRANCE}

Among the legitimate aspirations (1) of the working class, participation in the administration of undertakings is one which offers particular interest. Nowadays, workers demand more than suitable wages and working conditions : they wish to play a part within the undertaking, in short, they want to participate in the management of the undertaking. This is a problem of present interest which must be dealt with objectively.

Participation may be of three different kinds : a) participation in the form of an advisory body ; b) participation in the form of supervision; c) participation in the form of co-administration. The two first forms of participation do not affect the essential rights of Capital or of the head of an undertaking, while the third places both workers and shareholders on the same level.

$A$. - In Canada, as well as in Great Britain and the United States, participation of the various categories of the staff in advisory bodies has brought about most satisfactory results, especially as regards economic mobilization. Indeed, the joint production committees have closely associated the workers in the solving of the technical problems of production. Without encroaching upon the field of the syndicates, such boards have filled in a gap which has existed heretofore in industrial relations.

B. - In France, in February 1945, the Provisional Government passed an ordinance instituting " works committees $\%$. In acceding to a demand which has for long been on the programme of various syndicates, the Minister of Labour introduced supervisory participation, thus avoiding participation in the form of co-administration which had been requested by certain groups. The French works committees have a wider field of action and a more explicit part to play than our joint production committees. Their purpose is to ensure effective cooperation within the undertakings between the various factors concerned with production : i.e., management, technical staff and workers. The syndicates name the candidates that are to be members of the committees and, afterwards, their representatives are absolutely independent of the syndicates which have elected them. As to the functions of works committees, such functions are both social and economic.

1. In the social field, the functions of works committees consist in improving working conditions, excluding, however, questions relating to wages, which remain questions to be handled by the syndicates proper. The other social function of works committees consists in assuming or supervising the management of all the social welfare institutions established in the undertakings for the benefit of workers or their families.

2. In the economic field, works committees have advisory functions and are only allowed to look on. In virtue of their advisory functions the works committees will : a) study all the suggestions made by the staff for increasing production and improving the output

(1) "We consider it more advisable, however, in the present condition of human society that, so far as is possible, the workcontract be somewhat modified by a partnership-contract, as is already being done in various ways and with no small advantage to workers and owners. Workers and other employees thus become sharers in ownership or management or participate in some fashion in the profits received ${ }^{\prime}$. - Quadragesimo Anno. of the undertakings and make proposals concerning the application of the suggestions they favour ; b) propose rewards for workers who have, in the committee's opinion, been particularly useful to the undertaking by their initiative or suggestions. c) be constantly informed of questions pertaining to the organization, management and general operation - of the undertaking. At least once a year, management must present a general report on the situation and activities of the undertakings as well as on the plans made for the following period. Moreover, in the case of joint stock companies, or any other kind of company, regularly employing more than 500 workers, the committee must also be informed concerning the profits made and can voice suggestions as regards their use. Finally, in the case of limited liability companies, the management must communicate to the committee, before presenting them to the general meeting of the shareholders, the profit and loss account, the annual balance sheet and the report of the auditors and all other documents which would be submitted to the general meeting of the shareholders. Such are the main provisions of the Ordinance of February 1945.

C. - Participation in the form of co-administration is obviously more complete. In such a case, the representatives of the workers would be on an equal footing with the shareholders' representatives. Coadministration committees would have the power to take decision and give orders, while works committees have but advisory functions and a right to look on. This summary of the question shows the difference which exists between our joint production boards and works committees. While the latter are of a general, permanent and obligatory nature, our Canadian joint production boards are voluntary. Works committees have not only more authority, but employers are unable to avoid their formation. This formula is a compromise between integral co-administration of the undertaking and simple participation in the form of a consultative body. In the social field, the workers have administrative power, and in the economic field, their functions are merely consultative.

Nevertheless, the French ordinance represents a bold reform that many consider as a period of probation imposed upon the workers prior to their admission to administrative committees. All syndical organizations have adopted the following policy : " it is up to the workers to make works committees a success, and they may afterwards aspire to economic co-administration. " An objective analyst recently wrote : "In short, the Ordinance of February 22nd, 1945, has wisely taken foreign experience into account. It has created an institution which is compatible with the capitalist system of present undertakings and has therefore reformed the latter without upsetting them. It contains provisions ensuring the maintenance of management's authority, and others securing peaceable intercourse between the committees and syndical organizations." Such seems to be the general opinion in France.

Jean-Pierre Despres. 


\section{ESSENTIAL ELEMENTS OF TRADE UNION AGREEMENTS}

A sub-committee of the International Labour Office set up by the advisory committee on professional workers to study the essential elements of agreements and to formulate conclusions took steps to provide itself with the advice and opinion of experts chosen in such a way that they might be considered both as giving advice founded on their own experience and as expressing an opinion.representative of interested circles. National organisations were therefore consulted in the choice of these experts. The sub-committee submitted a questionnaire and $\mathbf{3 0}$ men constituting two almost equal groups, representing employers and employees respectively, gave it the benefit of their experience.

The consultation of the experts led sub-committee to the following conclusions :

a) Drafting of any agreement. - 1. The system of collective agreements is considered by the large majority of experts, both employers and employees, as of great utility and even necessary to good organisation and satisfactory development; 2 . Whenever possible the agreement should be drafted by means of direct negotiation between organisations in preference to any public intervention; 3. It would nevertheless be an advantage, in the eyes of the experts, if the application of any agreement drafted by the organisations were subsequently confirmed by law or order; 4. A regular procedure for the revision of agreements should be provided and defined.

b) The essential elements of an agreement are, according to the experts, as follows : 1 . Clauses dealing with termination of contract. The experts, both employers and employees, who dealt with the question, were almost unanimously of the opinion that it is necessary to distinguish previous notice from compensation for dismissal ; that there should not be reciprocity between employers and employees in respect of compensation, but that there should be complete reciprocity in respect of previous notice. The experts also considered it advisable to fix the amount of compensation in case of termination of agreements at the wish of the employer, but they were divided on the relative figures for compensa- tion in these various cases. The majority of the experts considered it necessary, though very difficult, to define the "grave fault " which may justify the termination of a contract without compensation. 2. Clauses on conditions of work. According to the general opinion of the experts who dealt with this question, the agreement should fix a minimum salary and holidays and regulate hours of work. 3. Clauses on welfare measures. The experts decided on the whole in favour of including welfare provisions in agreements. They did not go into details, with the exception of three employers who proposed the division of the cost between employer, employee and perhaps the State. 4. Clauses concerning settlement of claims. The experts showed a marked preference for special courts with joint representation, but with the participation of judges.

c) The sub-committee, finally, drew attention to the wish frequently expressed by the experts representing both employers and employees that joint bodies should be set up to provide for permanent collaboration between employers' and employees' associations and the discussion in common of questions relative to conditions of work.

The sub-committee, in view of the desire of the majority of the experts representing both employers and employees for the general adoption of the best forms of regulation and agreement, called on the advisory committee on professional workers to ask the governing body of the International Labour Office to decide on the following proposals : That the experts' advice and opinions should be communicated to the various governments and organisations concerned, and that the International Labour Office should be requested to give this study the utmost publicity ; and, further, that the International Labour Office should be requested to continue to follow with attention the development of the conditions of employment in various countries, with special reference to the questions of recruiting and protection - questions which were mentioned on several occasions by the experts, though it was not for the moment possible to indicate a solution.

Ambag, (Jan.), 1945. 


\title{
PRATIQUES INTERDITES AUX EMPLOYEURS ET AUX ASSOCIATIONS OUVRIÈRES
}

\author{
A titre documentaire, nous publions la section IV de la Loi des relations ouvrières de la province \\ de Québec (S.R.Q.,1941, chapitre 162A).
}

\section{SECTION IV}

PR ATIQUES INTERDITES

20. Aucun employeur, ni aucune personne agissant pour un employeur ou une association d'employeurs ne cherchera d'aucune manière à dominer ou à entraver la formation ou les activités d'une association de salariés.

Aucune association de salariés, ni aucune personne agissant pour le compte d'une telle association n'adhérera à une association d'employeurs, ni ne cherchera à dominer ou à entraver la formation ou les activités d'une telle association.

21. Aucun employeur, ni aucune personne agissant pour un employeur ou une association d'employeurs ne doit refuser d'employer une personne parce qu'elle est membre ou officier d'une association, ni chercher par intimidation, menace de renvoi ou autre menace, ou par l'imposition d'une peine ou par quelque autre moyen, à contraindre un salarié à s'abstenir de devenir membre ou officier ou à cesser d'être membre ou officier d'une association.

Le présent article n'a pas pour effet d'empêcher un employeur de suspendre, démettre, renvoyer ou déplacer un salarié pour une cause juste et suffisante dont la preuve lui incombe.

22. Nul ne doit user d'intimidation ou de menaces pour amener quiconque à devenir membre, à s'abstenir de devenir membre ou à cesser d'être membre d'une association.

23. Sauf avec le consentement de l'employeur, personne ne peut, au nom ou pour le compte d'une association,

a) solliciter pendant les heures de travail l'adhésion d'un salarié à une association, ou b) réunir au lieu du travail des salariés pour cette fin.

24. 1. Toute grève ou contre-grève est interdite tant qu'une association de salariés n'a pas été recoǹnue comme représentant du groupe de salariés en cause et tant que cette association n'a pảs fait les procédures voulues pour la conclusion d'une convention collective et qu'il ne s'est pas écoulé quatorze jours depuis la réception, par le ministre du travail, d'un rapport du conseil d'arbitrage sur le différend. Tant que les conditions ci-dessus n'ont pas été remplies, uñ employeur ne doit pas changer les conditions de travail de ses salariés sans leur consentement.

2. Toute grève ou contre-grève est interdite pendant la durée d'une convention collective tant que le grief n'a pas été soumis à l'arbitrage en la manière prévue dans ladite convention, ou à défaut de disposition à cette fin, en la manière prévue par la Loi des différends ouvriers de Québec chap. 167), et que quatorze jours ne se sont écoulés depuis que la sentence a été rendue sans qu'elle ait été mise à effet.

3 . Rien dans le présent article n'empêche une interruption de travail qui ne constitue pas une grève ou une contre-grève.

25. Nulle association ou personne agissant au nom d'une association n'ordonnera, n'encouragera ou ne supportera un ralentissement d'activités destiné à limiter la production.

26. Nulle association ayant conclu une convention collective, nul groupe d'employeurs ou de salariés membres d'une association ayant conclu une telle convention ne fera de démarches en vue de s'affilier à une autre association ou d'en devenir membre, sauf dans les soixante jours précédant la date d'expiration ou de renouvellement de la convention.

\section{CRISE DE CONFIANCE}

(Suile de la page 1)

en cause. En définitive, ni les employeurs ni les syndicats ouvriers ne bénéficient de cette violation de la législation. En plus, ce désordre constitue une invitation à l'intervention toujours plus grande du pouvoir exécutif dans les relations industrielles. C'est aussi un bon moyen d'en arriver au chaos et à la dictature.

Dans l'intérêt général, il est à souhaiter que les employeurs et les syndicats ouvriers en viennent à une conception plus juste de leurs droits et de leurs responsabilités. Plus ils obligeront l'État à intervenir, moins les uns et les autres conserveront leur autonomie et leur liberté.

La législation ouvrière la plus parfaite devient inefficace lorsque les employeurs et les syndicats préfèrent les solutions de force à la justice.

\section{A CRISIS OF DISTRUST}

(From page 1)

order and to the protection of the interests involved. As a result, neither the employers nor labour unions benefit by such violation of the law. Moreover, this disorder constitutes an invitation to the ever increasing intervention of the executive administration in industrial relations; it is also the surest way to chros and dictatorship.

For the benefit of the public, it is to be hoped that both the workers' unions and the employers will come to understand their rights and responsibilities. The more they oblige the State to intervene, the less they both will retain their autonomy and liberty.

The most perfect labour legislation is ineffectual if the employers and trade-unions prefer solution, by force to justice. 